OECD Education Working Papers No. 112

Student Behaviour and Use of Class Time in Brazil, Chile and Mexico: Evidence Gabriela Moriconi, from TALIS 2013 
Organisation de Coopération et de Développement Économiques

Organisation for Economic Co-operation and Development

30-Jan-2015

DIRECTORATE FOR EDUCATION AND SKILLS

English - Or. English

\section{STUDENT BEHAVIOUR AND USE OF CLASS TIME IN BRAZIL, CHILE AND MEXICO:} EVIDENCE FROM TALIS 2013

\section{Education Working Paper No. 112}

by Gabriela Miranda Moriconi, Fundação Carlos Chagas and Julie Bélanger, Organisation for Economic Co-Operation and Development

This paper was prepared by Gabriela Miranda Moriconi and Julie Bélanger during the Thomas J. Alexander Fellowship awarded to Gabriela Miranda Moriconi from September 2013 to September 2014.

Julie Bélanger, Analyst, EDU/ECS (julie.belanger@oecd.org)

Gabriela Miranda Moriconi, Fundaçao Carlos Chagas (gmoriconi@fcc.org.br)

JT03369943

Complete document available on OLIS in its original format

This document and any map included herein are without prejudice to the status of or sovereignty over any territory, to the delimitation of international frontiers and boundaries and to the name of any territory, city or area. 


\section{OECD EDUCATION WORKING PAPERS SERIES}

OECD Working Papers should not be reported as representing the official views of the OECD or of its member countries. The opinions expressed and arguments employed herein are those of the author(s).

Working Papers describe preliminary results or research in progress by the author(s) and are published to stimulate discussion on a broad range of issues on which the OECD works. Comments on Working Papers are welcome, and may be sent to the Directorate for Education and Skills, OECD, 2 rue André-Pascal, 75775 Paris Cedex 16, France.

This document and any map included herein are without prejudice to the status of or sovereignty over any territory, to the delimitation of international frontiers and boundaries and to the name of any territory, city or area.

You can copy, download or print OECD content for your own use, and you can include excerpts from OECD publications, databases and multimedia products in your own documents, presentations, blogs, websites and teaching materials, provided that suitable acknowledgement of OECD as source and copyright owner is given. All requests for public or commercial use and translation rights should be submitted to rights@oecd.org.

Comment on the series is welcome, and should be sent to edu.contact@ oecd.org.

This working paper has been authorised by Andreas Schleicher, Director of the Directorate for Education and Skills, OECD.

www.oecd.org/edu/workingpapers

COPYRIGHT @ OECD 2015 
EDU/WKP(2015)1

\begin{abstract}
Teachers in Brazil, Chile and Mexico report having high percentages of students with behavioural problems in their classes. Especially in Brazil, teachers report spending large amounts of time keeping order in the classroom. Besides potentially significantly reducing instructional time and students' opportunities to lean, student misbehaviour can also influence attracting and retaining teachers. Therefore, this paper aims to investigate factors associated with time that lower secondary teachers report spending keeping order in the classroom and factors associated with these teachers' reports of student behavioural problems in their class. It is based on in-depth analyses from the OECD Teaching and Learning International Survey (TALIS 2013) data from Brazil, Chile and Mexico. Some of the major findings show that aspects of initial teacher education, professional development and teacher professional collaboration are associated with the time that lower secondary teachers report spending keeping order in the classroom, while participation among stakeholders in schools is negatively associated with student behavioural problems in the classroom.
\end{abstract}

\title{
Résumé
}

Au Brésil, au Chili et au Mexique, les enseignants font état d'importants pourcentages d'élèves ayant des problèmes de comportement dans leurs classes. Au Brésil plus particulièrement, les enseignants indiquent consacrer beaucoup de temps au maintien de l'ordre en classe. En plus de réduire potentiellement de façon significative le temps d'instruction et les opportunités d'apprentissage, les problèmes de comportement des élèves peuvent également avoir une incidence sur l'attrait de la profession d'enseignant et le maintien des enseignants déjà en poste. Cet article document entend donc étudier les facteurs associés au temps que les enseignants du premier cycle du secondaire indiquent consacrer au maintien de l'ordre en classe et les facteurs associés aux déclarations que font ces enseignants de comportements perturbateurs d'élèves dans leurs classes. Il se fonde sur des analyses approfondies des données de l'Enquête internationale de l'OCDE sur l'enseignement et l'apprentissage (TALIS 2013) pour le Brésil, le Chili et le Mexique. Parmi les principaux résultats, il apparaît que certains aspects de la formation initiale des enseignants, de leur formation continue et de leur collaboration professionnelle entre pairs présentent un lien avec le temps que les enseignants du premier cycle du secondaire indiquent consacrer au maintien de l'ordre en classe, tandis que la participation des différents acteurs de l'établissement présente une relation négative avec les problèmes de comportement des élèves en classe. 


\section{TABLE OF CONTENTS}

\section{STUDENT BEHAVIOUR AND USE OF CLASS TIME IN BRAZIL, CHILE AND MEXICO:

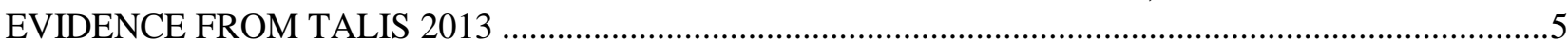

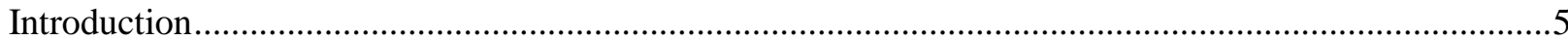

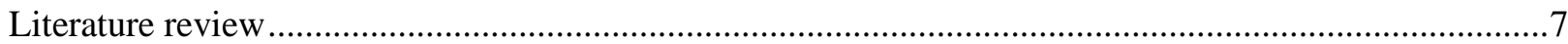

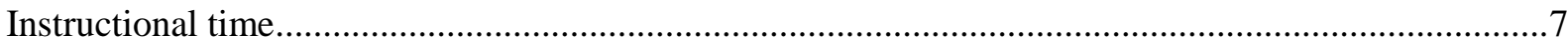

Research on student behaviour and use of class time in Latin American schools .................................8

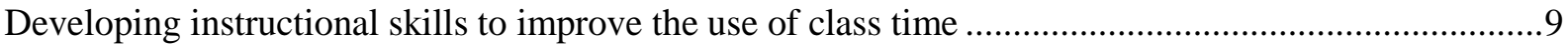

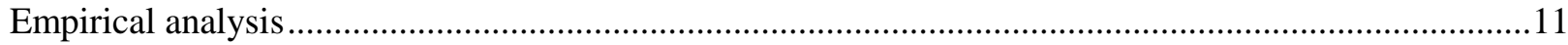

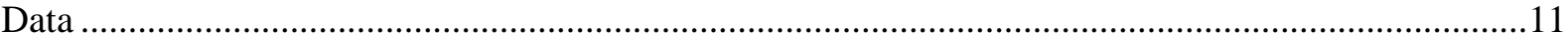

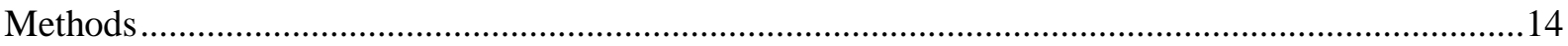

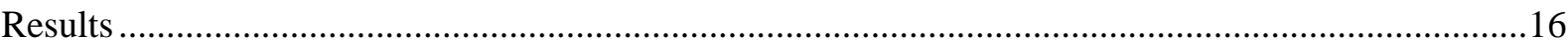

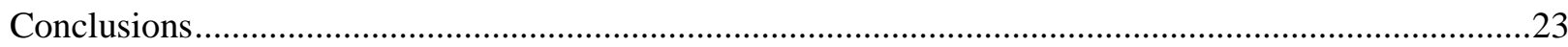

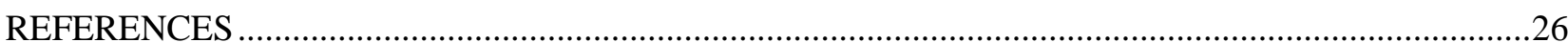

\section{Tables}

Table 1. Participation on TALIS and estimated size of lower secondary teacher population from Brazil, Chile and Mexico ..................................................................................................12

Table 2. Teachers from TALIS 2013 who were excluded and who remained in the analysis ............12

Table 3. Characteristics of Teachers, Classes and Schools in the analysis.......................................13

Table 4. Variables included in the model for the analysis of time keeping order ................................15

Table 5. Variables included in the model for the behavioural problems analysis ............................16

Table 6. Time keeping order analysis - empty model..................................................................17

Table 7. Time keeping order analysis - estimates with behavioural problems variables .....................18

Table 8. Time keeping order analysis - estimates with socioeconomic variables .............................19

Table 9. Time keeping order analysis - estimates with type of school management variable (public or

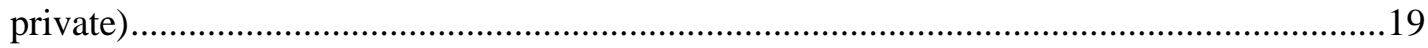

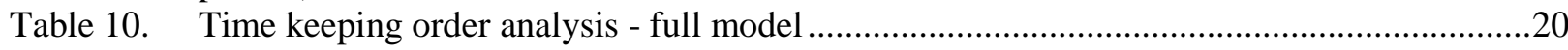

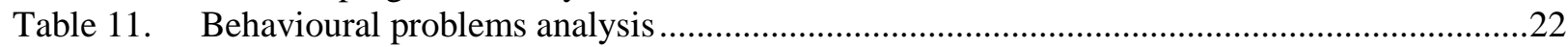

\section{Figures}

Figure 1. Percentage of lower secondary teachers who report having more than $10 \%$ of their students with behavioural problems in a target class.........................................................................6

Figure 2. Proportion of class time lower secondary teachers spend keeping order in a target class -

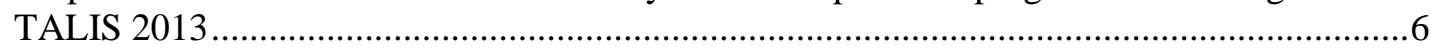

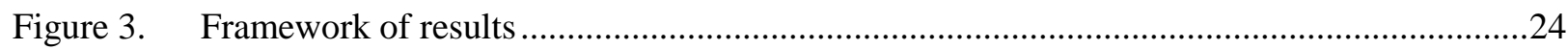




\section{STUDENT BEHAVIOUR AND USE OF CLASS TIME IN BRAZIL, CHILE AND MEXICO: EVIDENCE FROM TALIS 2013 ${ }^{1}$}

\section{Introduction}

In addition to frequently being the focus of media reports and professional literature, classroom management and student discipline are some of the most commonly cited concerns by teachers (McCormack, 1997; Husu, 2003). Moreover, student discipline and behavioural problems are some of the areas for which teachers in many countries report the highest levels of need for professional development (OECD, 2009, 2014a; Jensen et al., 2012).

Classrooms with severe disciplinary problems are less conducive to learning because teachers have to spend time dealing with disruptions instead of actually engaging in teaching and learning activities. Keeping order in the classroom can really consume a large proportion of class time, reducing students' opportunities to learn (Cotton, 1989).

Student misbehaviour also contributes to teacher dissatisfaction and stress, affecting teachers' attraction and retention. Along with low wages and low social status, student behaviour is one of the most cited reasons for Brazilian high school students deciding not to enter the teaching profession (Tartuce et al., 2010).

According to data from the OECD's Teaching and Learning International Survey (TALIS), teachers' perceptions of the level of student behavioural problems and disciplinary climate vary a great deal among countries around the world (OECD, 2009, 2014a). While more than 60\% of lower secondary teachers report having more than $10 \%$ of students with behavioural problems in Brazil, the number is much lower in Japan, where only $13 \%$ of teachers report the same (OECD, 2014a) ${ }^{2}$. Teachers in Chile and Mexico, the two other Latin American countries that participated in TALIS 2013, also report high levels of student behavioural problems in their classes.

1. The first author received funding from the OECD Thomas J. Alexander fellowship program for carrying out this work. The work should not be reported as representing the official views of the OECD or of its member countries. The opinions expressed and arguments employed herein are those of the author(s).

2. This is based on teachers' answers to the question: "Please estimate the broad percentage of students who have the following characteristics - Students with behavioural problems". 
Figure 1. Percentage of lower secondary teachers who report having more than $10 \%$ of their students with behavioural problems in a target class ${ }^{3}$

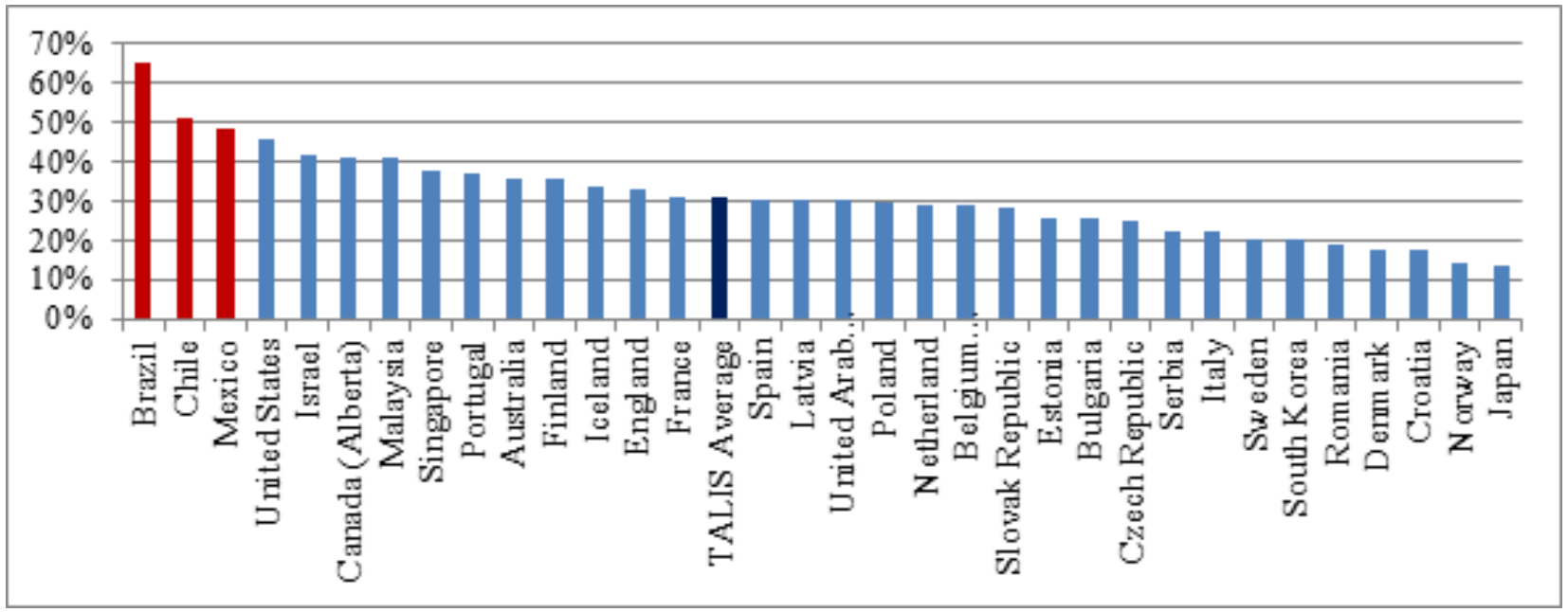

Source: OECD TALIS 2013 database.

Student misbehaviour can be associated with a reduction in students' opportunities to learn - especially in Brazil. Among all countries that participated in TALIS in both 2008 and 2013, teachers in Brazil report spending the highest proportion of class time keeping order in the classroom (18\% in 2008 and $20 \%$ in 2013, compared to an international average of $13 \%$ in both years). Chilean teachers are also among the countries in which teachers report spending higher proportions of class time with disciplinary tasks, while Mexico is slightly below TALIS countries' average.

Figure 2. Proportion of class time lower secondary teachers spend keeping order in a target class - TALIS 2013

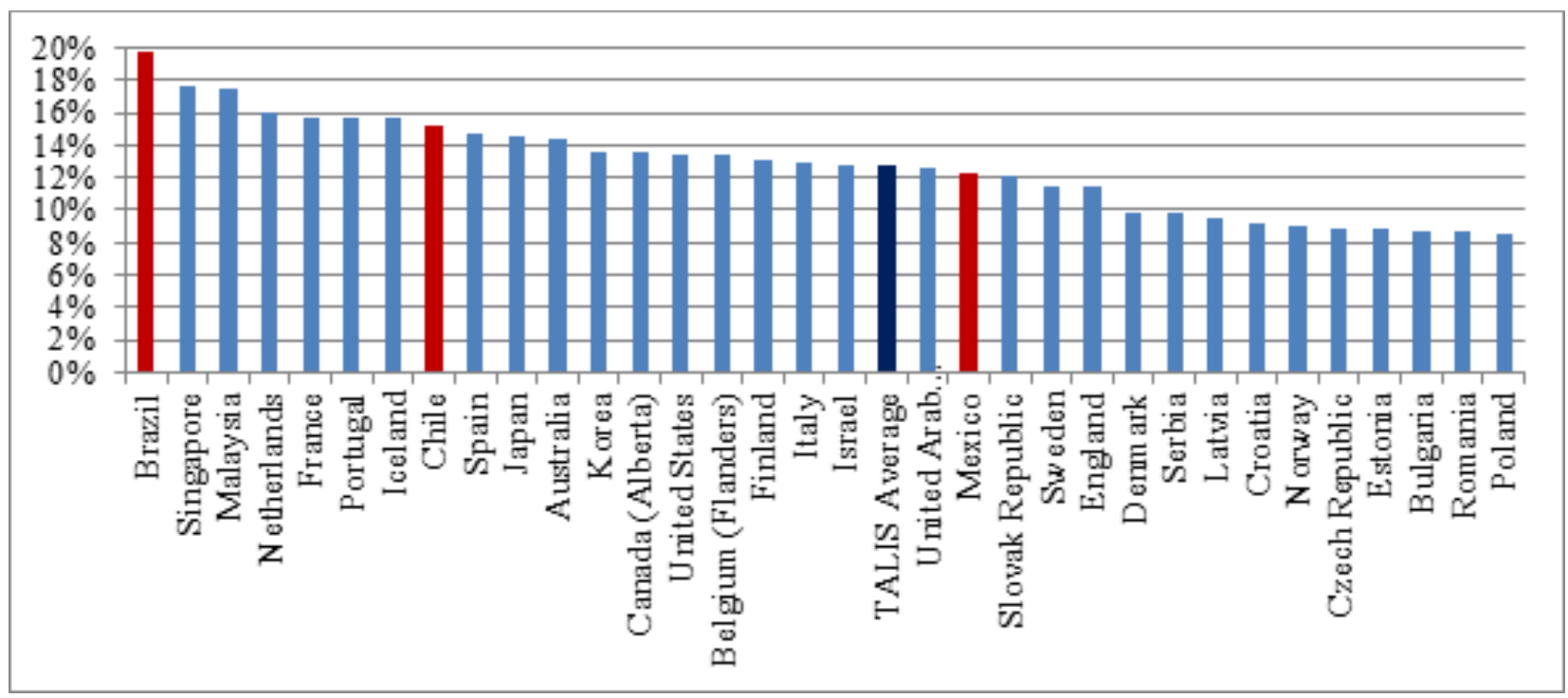

Source: OECD TALIS 2013 database.

3. The target class that teachers are asked to respond to is the first that they taught in that school after 11 a.m. on the previous Tuesday. This is the strategy used by TALIS to obtain data from an average lesson for each country. 
Although student misbehaviour can certainly result in teachers spending more time maintaining discipline in the classroom, it is not the only factor that influences teachers' use of class time. The first goal of this paper is to investigate other factors which might be associated with the time teachers report spending keeping order in the classroom, particularly focussing on aspects of teachers' initial preparation and engagement in professional collaboration. In doing so, the paper also aims to identify areas where policies might better support teachers in dealing with student behavioural problems in their classroom.

Enhancing teachers' capacity to deal with student behaviour should also be accompanied with other strategies to reduce disciplinary problems and improve school climate. A second goal of this paper is therefore to better understand the factors associated with student behavioural problems in order to identify ways to reduce their incidence.

The study is based on in-depth analyses of TALIS 2013 data from the three Latin American countries participating in the survey: Brazil, Chile and Mexico. As mentioned earlier, teachers in all three countries report having high percentages of students with behavioural problems in their classes. Besides potentially reducing actual instructional time, student misbehaviour can also influence attracting and retaining teachers in all three countries and is therefore of great policy relevance.

This paper is further divided into three sections. The next section presents a brief literature review on the use of time in schools and classrooms. The following section contains the empirical analyses and the last section presents the conclusions of these analyses.

\section{Literature review}

\section{Instructional time}

Instructional time can be defined as the portion of classroom time actually spent teaching students particular knowledge, concepts and skills pertaining to school subjects (Karweit and Slavin, 1981; Cotton, 1989), and can also be defined as a kind of "net measure of engaged teaching time" (Scheerens and Hendricks, 2014). TALIS measures teachers' perceptions of instructional time by asking them to report the percentage of class time they typically spend on actual teaching and learning.

There are many factors that may reduce the amount of time during which students are actually being taught. These factors can be divided into two groups: those which occur before teaching starts - before classes or between classes - and those which occur after instruction starts - during classes.

Students' opportunities to attend classes may be reduced by several factors, including parties, assemblies, medical screening, high-stakes examination, school closings due to inclement weather and teacher strikes (Smith, 1998; Karweit, 1984). In developing countries, the school's physical condition and poor infrastructure (e.g. no roof or no walls, high noise levels, lack of ventilation or heating, lack of water), natural calamities and political and social conflicts can also represent a relevant problem (EARC, 2003; Benavot and Gad, 2004; Abadzi, 2007). These types of problems still affect some Latin American schools, especially those in poorer areas of large urban cities or rural areas.

Due to low relative salaries, bad working conditions and/or difficult contexts, many educational systems have difficulties hiring and retaining teachers, sometimes even more so in schools located in poorer areas of large urban cities or rural areas (EARC, 2003). Since there is not always a substitute or permanent teacher to replace one who left, students may spend days or even months without classes in a specific subject. Teacher absenteeism can also be a factor that reduces instructional time (Abadzi, 2007). According to TALIS 2013, between $18 \%$ and $21 \%$ of lower secondary teachers in Brazil, Chile and Mexico work in schools where the principal reports that teacher absenteeism occurs at least weekly (OECD, 2014a). 
Shortages of teachers and schools, especially in areas of high demand, also result in overcrowded classes, with potential negative impact on the use of time in the classroom. According to TALIS 2013, in Brazil, Chile and Mexico, the average class size in lower secondary is around 30 students, though in some schools the average reaches 50 students in Brazil and Mexico, and 60 students in Chile. This means that a significant group of teachers in these countries must engage more than 50 lower secondary students and maintain a good disciplinary climate in the classroom - which can be a very challenging task.

Besides student interruptions (e.g. disruptive behaviour, peer conflicts) and teacher interruptions (e.g. disciplinary actions, calling the office) there are other sources of lost instructional time such as administrative tasks (e. g. recording attendance, handing out school information) (Karweit, 1984; Smith, 1998); transitions; and later starts and early dismissals (Hollowood et al., 1995). Smith (1998) found that, on average, the rate of non-instructional time in Chicago public schools observed in her study was $23 \%$. In TALIS 2013, the average rate of non-instructional time reported by teachers ranged from $13 \%$ in Bulgaria to $33 \%$ in Brazil - with an average of $21 \%$ among the participating countries. The average rate of noninstructional time was $26 \%$ in Chile and $24 \%$ in Mexico.

Although there are other factors affecting time in the classroom, behavioural problems have been identified as major causes of loss of instructional time (Cotton, 1989; Ratcliff et al., 2010). TALIS 2013 results support this idea. Teachers in TALIS 2013 report spending, on average, more class time dealing with student discipline $-13 \%$ of class time - than on administrative tasks $-8 \%$ of class time.

\section{Research on student behaviour and use of class time in Latin American schools}

Although there is growing interest in how time is used inside the classrooms of Latin American schools, there are only a few studies on this topic in the region. This section provides a very brief review of the evidence in the region.

Carnoy, Gove and Marshall (2009) compared classrooms in Brazil, Chile and Cuba based on observations of $3 \mathrm{rd}$ grade mathematics lessons. ${ }^{4}$ The results suggested that Cuban classes were considered more efficient than Chilean, and especially Brazilian classes, since less instructional time was lost due to transitions and interruptions. The authors affirm that the Brazilian sample was found to be consistently less engaged: Brazilian students were sometimes visibly bored with the class or completely off task. In contrast, Cuban students were consistently engaged and rarely presented body language that suggested a lack of interest. Between those two extreme cases, they found the Chilean students: in private schools, student engagement was similar to Cuban schools, but in public schools, the average was similar to Brazilian schools. They point to the same difference in terms of disciplinary climate: in Cuban and Chilean private schools, the classes had more orderly climate than Brazilian and Chilean public schools.

One possible reason for these results is lack of planning, which may be caused by lack of skills or time - or both. Carnoy, Gove and Marshall (2009) found that Brazilian students spent much more time copying instructions from the board than students from Chile and Cuba. Teachers used activities that were already prepared in only a few Brazilian schools- which, in contrast, was commonly observed in Chile and Cuba. The authors emphasise that having to copy mathematics problems from the board before starting to solve them affected the use of time in the classroom.

Another possible reason is related to teaching style and opportunities for students to engage in learning during classes. The evidence from municipal schools in Chile shows that the predominant

4. While Carnoy et al. (2009) examines an earlier level of education than is the focus of this paper, it provides interesting insights on educational practices in these countries that are likely to be found also in subsequent levels of education, and is therefore included in this brief review of the literature. 
teaching style is characterised by directive pedagogy (Martinic and Vergara, 2007; Martinic, Vergara and Huepe, 2013), in which most of the class time is spent by the teacher speaking to the whole class. In those classes, most of the speech is focused on exposing content and explaining procedures, and is directed to an "average student", from which we can infer that differentiated instruction is not a common practice (Martinic and Vergara, 2007; Martinic, Vergara and Huepe, 2013). A lower proportion of time is invested in questions directed to students. Questions are focused on controlling the class flow and checking information, being considered as of low cognitive complexity (González, Preiss and San Martín, 2008; Preiss, 2009).

Moreover, there has been some evidence of inequalities in the use of class time, depending on the socioeconomic status (SES) of students in Chile and Brazil. Carnoy, Gove and Marshall (2009) noted important differences in content level and intensity of tasks according to student background in both countries. These differences have been highlighted by other studies in Latin America. De La Cruz et al. (2001) observed that students from poorer sectors in Argentina are more exposed to questions of low cognitive complexity than students from wealthier sectors. Teachers in schools serving students from more disadvantaged homes usually emphasise disciplinary aspects over cognitive aspects (De La Cruz et al. 2001; Martinic, Vergara and Huepe, 2013).

There is some evidence that cumulative factors might be at stake in Latin American schools: On the one hand, Carnoy, Gove and Marshall (2009) observed that students from socio-economically disadvantaged homes sometimes arrive at school with worse physical and emotional conditions, and may also find worse school conditions to support their learning. On the other hand, based on their observations in Argentinian schools, De La Cruz et al. (2001) affirm that teachers tend to shape their teaching according to the representations they make of students from different backgrounds. Specifically, teachers tend not to go as deeply into the content for students in disadvantaged areas, because they believe these students to be less able to understand what students from more advantaged backgrounds might more easily understand.

Among the many conditions needed to reduce the loss of instructional time and engage students in learning, none can substitute teachers' effective teaching and classroom management (Hawley et al., 1984; Smith, 1998; Gettinger and Seibert, 2002; Oliver, Wehby and Reschly, 2007). Teachers displaying effective practices have higher proportions of instructional time (Smith, 1998) and of student time on task (Espin and Yell, 2001). Although no study examining the effects of teacher pedagogical skills on the use of class time was found in Latin America, studies from other educational systems may help shed some light on initiatives that could support Latin American teachers in developing these skills and, therefore, in improving their use of class time.

\section{Developing instructional skills to improve the use of class time}

Darling-Hammond, Wise, and Kline (1999) described teaching skills as follow:

Teaching skills include the abilities to transform knowledge into actions needed for effective teaching - for example, abilities to evaluate student thinking and performance in order to plan appropriate learning opportunities; abilities to critique, modify, combine, and use instructional materials to accomplish teaching and learning goals; abilities to understand and use multiple learning and teaching strategies; abilities to explain concepts clearly and appropriately, given the developmental needs and social experiences of students; abilities to provide useful feedback to students in constructive and instructionally helpful ways. (p.39)

One of the main contributions to the discussion about this knowledge required to be transformed into effective teaching is given by Shulman (1987). Shulman's (1987) knowledge base for teaching includes: (1) content knowledge; (2) general pedagogical knowledge; (3) curriculum knowledge; (4) pedagogical 
content knowledge; (5) knowledge of learners; (6) knowledge of educational contexts; and (7) knowledge of educational ends, purposes and values. The author particularly emphasises the pedagogical content knowledge, which "represents the blending of content and pedagogy into an understanding of how particular topics, problems or issues are organised, represented, and adapted to the diverse interests and abilities of learners, and presented for instruction" (Shulman, 1987, p. 8).

Shulman's (1987) knowledge base for teaching influenced teacher initial education in many countries (Darling-Hammond and Lieberman, 2012). For example, it inspired the reform of the teaching profession and the design of teacher initial education programs in Singapore (Goodwin, 2012), and it may be seen in the ideas of teacher educators in Finland (Sahlberg, 2012) - two systems seen as leaders in the educational field.

However, teacher initial education is not the only way to enhance teachers' pedagogical knowledge and skills. Many studies have shown that competencies in pedagogical strategies and classroom management can be improved through specifically designed activities of professional development (Supovitz and Turner, 2000; Garet et al., 2001; Desimone et al, 2002; Darling-Hammond et al., 2009). Some characteristics of professional development considered to be effective in improving teaching practices are: (1) content focus; (2) coherence; (3) active learning; (4) frequency and duration; and (5) collective participation and collaboration (Garet et al., 1999, 2001; Desimone, 2009; Darling-Hammond et al., 2009).

First, professional development should address concrete, everyday challenges involved in teaching and learning specific academic subject matter, rather than focus on abstract educational principles or teaching methods taken out of context (Darling-Hammond et al., 2009). Improving teachers' knowledge of subject-matter content and pedagogy is necessary for teachers who received insufficient or inadequate initial education or training (Davis et al., 2011), but is also important to ensure that all teachers adapt to changes in current understanding of subjects (Hawley and Valli, 1999).

Second, there is a need for coherence among professional development and the guidance that teachers receive from multiple sources about what they are required to do, such as curriculum guidelines, textbooks, assessments, teacher pre-service education, and so on (Garet et al., 1999; Supovitz, Mayer and Kahle, 2000). If there is a disconnect between what teachers learn during professional development and what is required by other systems or school policies, teachers are less likely to implement the strategies learned in professional development in their classroom (Darling-Hammond et al., 2009).

Third, teacher professional development should not be restricted to listening to lecturers talking about abstractions and generalities: it must engage teachers in concrete teaching tasks, such as planning lessons and evaluating students' work (Darling-Hammond and McLaughlin, 1995; Garet et al., 2001). Lieberman (1995) argues that for teachers to change their teaching they must have the opportunity to "talk, think, try out, and hone new practices, which means they must be involved in learning about, developing and using new ideas with their students" (p. 189).

Fourth, teacher professional development should be sustained over time (Hawley and Valli, 1999; Garet et al., 1999; Supovitz and Turner, 2000). Professional development that occurs in a continuous way (rather than one-off presentations) and at regular intervals is most effective for supporting changes in teachers' practices (Lieberman, 1995; Garet et al., 2001). More intensive activities are more likely to provide an opportunity for in-depth discussion, while activities that extend over time are more likely to allow teachers to try out new practices in the classroom and obtain feedback on their teaching (Garet et al., 1999). 
Fifth, professional development can be conceived as a process of professional collaboration (DarlingHammond and McLaughlin, 1995; Hawley and Valli, 1999). Garret et al. (1999) indicate that collective participation in professional development may help contribute to a shared professional culture, in which teachers in a school, or teachers who teach the same grade or subject may all develop a common understanding of pedagogical goals, methods, problems and solutions. Hawley and Valli (1999) affirm that learning opportunities organised around collaborative problem solving give teachers the opportunity to work together to address issues of common concern, which enables not only teacher change, but also school change.

Collaboration among teachers and other members of the school community is also important to overcome school challenges, such as poor school climate. This is of particular relevance for this study, since it is hard to maintain a good classroom climate if there is a bad school climate. For example, Porter (2006) recommends involving the school community when developing a school-wide disciplinary policy that provides a framework for preventing and intervening with disruptions. Wide consultation with staff, students and parents through the process improves policy effectiveness, besides being a moral obligation (Porter, 2006).

This short review of the relevant literature suggests that these aspects of teacher initial education, professional development and professional collaboration can be important ways of developing teacher pedagogical skills, and therefore help teachers implement strategies to better engage their students in learning. The main hypotheses of this paper are therefore that teachers in Brazil, Chile and Mexico who take part in these types of initiatives will be more likely to develop skills that will allow them to engage their students in learning and will spend a smaller proportion of time keeping order in their classroom.

The next section will present the analyses that investigate if these and other school and classroom conditions are associated with student behaviour, and teachers' reported use of class time.

\section{Empirical analysis}

\section{Data}

These analyses are based on data from TALIS $2013 .^{5}$ TALIS is an international, large-scale survey that focuses on the working conditions of teachers and the learning environment in schools. The first cycle of TALIS was conducted in 2008 and surveyed teachers and school leaders of lower secondary education in 24 countries. In the second cycle, TALIS 2013 expanded to include additional countries, with a total of 34 participants (OECD, 2014a, 2014b).

The target sample size for TALIS is 200 randomly selected lower-secondary schools per country, with 20 randomly selected teachers and 1 school leader per school. Brazil opted to sample in such a way so as to represent the state system of education and the set of municipal systems of education in each of the 26 states of the Brazilian federation, plus the Federal District system of education. This resulted in a much larger number of participating schools and teachers in Brazil than in the other participating countries, as shown in Table 1.

5. The complete database from TALIS 2013 is available at:

http://stats.oecd.org/Index.aspx?datasetcode=talis $2013 \% 20$ 
Table 1. Participation on TALIS and estimated size of lower secondary teacher population from Brazil, Chile and Mexico

\begin{tabular}{llll}
\hline & Brazil & Chile & Mexico \\
\hline Number of participating schools & 1070 & 178 & 187 \\
\hline Responding teachers in participating schools & 14291 & 1676 & 3138 \\
\hline School participation before replacement (\%) & 97 & 88 & 95 \\
\hline School participation after replacement (\%) & 97 & 91 & 96 \\
\hline Teacher participation in participating schools (\%) & 94 & 93 & 91 \\
\hline Overall participation (\%) & 91 & 85 & 87 \\
\hline Weighted estimated size of teacher population & 594874 & 51632 & 250831 \\
\hline
\end{tabular}

Source: OECD (2014a) - Table A.2.

From all the teachers participating in TALIS 2013, only the ones with a valid answer to the question "What percentage of class time is typically spent on each of the following activities?" and to the question "Please estimate the broad percentage of students (in the target class) who have the following characteristics - Students with behavioural problems" remained in the analysed database. ${ }^{6}$

Table 2 shows the number and proportion of schools and teachers used in the analysis.

Table 2. Teachers from TALIS 2013 who were excluded and who remained in the analysis

\begin{tabular}{|c|c|c|c|c|c|c|}
\hline & Brazil & & Chile & & Mexico & \\
\hline & Number & $\%$ & Number & $\%$ & Number & $\%$ \\
\hline $\begin{array}{l}\text { Reported teaching in the target } \\
\text { class directed entirely or mainly } \\
\text { to special needs students }\end{array}$ & 1036 & $7 \%$ & 320 & $19 \%$ & 219 & $7 \%$ \\
\hline $\begin{array}{l}\text { Did not reach the class time } \\
\text { question }\end{array}$ & 939 & $7 \%$ & 95 & $6 \%$ & 23 & $1 \%$ \\
\hline $\begin{array}{l}\text { Omitted or gave an invalid } \\
\text { answer to the class time } \\
\text { question }\end{array}$ & 1,922 & $13 \%$ & 167 & $10 \%$ & 214 & $7 \%$ \\
\hline $\begin{array}{l}\text { Omitted or gave an invalid } \\
\text { answer to the student } \\
\text { behavioural problems question }\end{array}$ & 129 & $1 \%$ & 17 & $1 \%$ & 14 & $0 \%$ \\
\hline $\begin{array}{l}\text { Teachers kept in the analysed } \\
\text { sample }\end{array}$ & 10265 & $72 \%$ & 1,077 & $64 \%$ & 2668 & $85 \%$ \\
\hline $\begin{array}{l}\text { Weighted estimated size of } \\
\text { teacher population being } \\
\text { analysed }\end{array}$ & 432,905 & & 32322 & & 213461 & \\
\hline $\begin{array}{l}\text { Number of schools in the } \\
\text { analysis }\end{array}$ & 1056 & $99 \%$ & 172 & $97 \%$ & 187 & $100 \%$ \\
\hline
\end{tabular}

Source: OECD TALIS 2013 database.

6. The complete questionnaires from TALIS 2013 are available in OECD (2014b) and at www.oecd.org/talis. 
The analysis contains $72 \%, 64 \%$ and $85 \%$ of responding teachers in Brazil, Chile and Mexico, respectively. Half of the exclusions in Brazil and Mexico, and more than half in Chile, were not related to the class time and student behaviour questions: teachers either reported teaching entirely or mainly to special needs students or they did not reach the class time question when filling in the questionnaire. Furthermore, all the original schools remained in the Mexican database and almost all of them remained in the Brazilian and Chilean databases. Thereby, the teachers and schools that remained in the databases do not seem to represent a biased sample in these countries.

The characteristics of teachers, classes and schools analysed are presented in Table 3.

Table 3. Characteristics of Teachers, Classes and Schools in the analysis

\begin{tabular}{|c|c|c|c|}
\hline & Brazil & Chile & Mexico \\
\hline \multicolumn{4}{|l|}{ Teacher/Class characteristics } \\
\hline Proportion of class time keeping order in the classroom & $20 \%$ & $15 \%$ & $12 \%$ \\
\hline $\begin{array}{l}\text { Proportion of teachers with more than } 10 \% \text { students with behavioural problems in the } \\
\text { class }\end{array}$ & $64 \%$ & $48 \%$ & $47 \%$ \\
\hline $\begin{array}{l}\text { Proportion of teachers with more than } 10 \% \text { students from socio-economically } \\
\text { disadvantaged homes in the class }\end{array}$ & $63 \%$ & $57 \%$ & $63 \%$ \\
\hline Years of teaching experience & 13.4 & 15.3 & 15.4 \\
\hline Gender (female) & $71 \%$ & $61 \%$ & $54 \%$ \\
\hline Class size & 30.9 & 31.8 & 33.0 \\
\hline The subject of the class was included in the initial training & $90 \%$ & $91 \%$ & $92 \%$ \\
\hline The pedagogy of some or all subjects taught was included in formal education & $81 \%$ & $91 \%$ & $90 \%$ \\
\hline The practice of some or all subjects taught was included in formal education & $90 \%$ & $84 \%$ & $82 \%$ \\
\hline $\begin{array}{l}\text { Participated in professional development on the knowledge of the subject with large } \\
\text { perceived impact on their teaching }\end{array}$ & $30 \%$ & $21 \%$ & $31 \%$ \\
\hline $\begin{array}{l}\text { Participated in professional development on pedagogical competencies of the subject with } \\
\text { large perceived impact on their teaching }\end{array}$ & $26 \%$ & $18 \%$ & $28 \%$ \\
\hline $\begin{array}{l}\text { Participated in professional development on student behaviour and classroom } \\
\text { management with large perceived impact on their teaching }\end{array}$ & $11 \%$ & $12 \%$ & $20 \%$ \\
\hline \multicolumn{4}{|l|}{ School characteristics } \\
\hline $\begin{array}{l}\text { Schools with more than half teachers with more than } 10 \% \text { of students with behavioural } \\
\text { problems }\end{array}$ & $77 \%$ & $44 \%$ & $47 \%$ \\
\hline $\begin{array}{l}\text { Schools with more than half teachers with more than } 10 \% \text { of students from socio- } \\
\text { economically disadvantaged homes }\end{array}$ & $70 \%$ & $59 \%$ & $77 \%$ \\
\hline Publicly managed school & $81 \%$ & $36 \%$ & $81 \%$ \\
\hline School size (enrolment) & 761.5 & 673.6 & 584.0 \\
\hline School located in a city or large city (more than 100000 inhabitants) & $38 \%$ & $50 \%$ & $57 \%$ \\
\hline
\end{tabular}

Source: OECD TALIS 2013 database.

As Table 3 shows, there are some similarities among the characteristics of teachers and classes in the three countries. There are between 31 and 33 students per class, on average; most of the teachers report that the content, the pedagogy and the practice of the subjects they teach were included in their formal education (more than 80\%); and a small proportion of teachers who participated in professional development perceived a large impact of this development on their work (less than 31\%). However, there are striking differences between them as well. As mentioned earlier, Brazilian teachers report having higher proportions of students with behavioural problems and spending more time keeping order in the 
classroom than Chilean and Mexican teachers. Also, while most schools in Brazil and Mexico are publicly managed, in Chile the opposite is the case - although a large part of them may be publicly funded.

\section{Methods}

This paper has two main goals. The first purpose of this work is to identify the factors that are associated with the percentage of time teachers report spending keeping order in the classroom. The analyses take into account the hierarchical nature of the TALIS data, in which teachers (and their classes) are nested within schools, and schools are nested within countries. Teachers within a school share the same school population, climate and internal procedures. Because of this, it is expected that two teachers randomly chosen within the same school will tend to spend more similar amounts of time keeping order in the classroom than two teachers randomly chosen from different schools. Hierarchical linear models (HLM) are commonly used in the educational field due to their capacity to deal with the hierarchical nature of educational data (Raudenbush and Bryk, 2002; Snijders and Bosker, 1999).

In this model, the dependent variable is the percentage of class time each teacher reports spending keeping order in the classroom, which may theoretically vary from 0 to $100 \%$. The explanatory variables were created based on the questions available in TALIS that represent issues presented in the literature review, but also some other factors that might be associated with the time spent keeping order in the classroom.

Variables related to aspects of teacher initial education and professional development are of particular interest since they represent factors that may be improved by educational policies in order to improve teachers' skills for teaching and classroom management. In terms of teacher education, variables indicating whether or not it included the content and the pedagogy of the content currently being taught by the teacher - representing Shulman's (1987) pedagogical content knowledge - as well as classroom practices were included. In terms of professional development, variables indicating teachers' reported participation in activities, which included content knowledge and pedagogical content knowledge, as well as student behaviour and classroom management, were also included in the analyses. The variables related to teacher preparation also included two indices of effective professional development and professional collaboration. These indices contain the features discussed in the literature review and are described in Table 4, which presents all the variables included in this model. The hypothesis of this analysis is that teachers who report having participated in these initial teacher education, professional development and collaboration activities developed better teaching and classroom management skills and, therefore, will report spending less time keeping order in the classroom - all the control variables being held constant. Among the control variables are context variables, such as student behaviour and socio-economic background. Control variables are also presented in Table 4. 
Table 4. Variables included in the model for the analysis of time keeping order

\begin{tabular}{|c|c|}
\hline \multicolumn{2}{|l|}{ Dependent Variable } \\
\hline $\begin{array}{l}\text { Class time keeping } \\
\text { order }\end{array}$ & $\begin{array}{l}\text { Percentage of class time spent keeping order in the classroom in the target class (from } \\
0 \text { to } 100 \% \text { ) }\end{array}$ \\
\hline \multicolumn{2}{|c|}{ Independent Variables } \\
\hline \multicolumn{2}{|c|}{ Teacher/Class Level Variables } \\
\hline Student behaviour & $\begin{array}{l}\text { Percentage of students with behavioural problems in the target class }(10 \% \text { or less }=0 ; \\
\text { more than } 10 \%=1)\end{array}$ \\
\hline $\begin{array}{l}\text { Student } \\
\text { socioeconomic } \\
\text { background }\end{array}$ & $\begin{array}{l}\text { Percentage of students from socioeconomically disadvantaged homes in the target } \\
\text { class }(10 \% \text { or less }=0 ; \text { more than } 10 \%=1)\end{array}$ \\
\hline Teacher experience & Teaching experience (number of years) \\
\hline Teacher gender & Gender (female $=1 ;$ male $=0$ ) \\
\hline Class size & Class size (number of students in the target class) \\
\hline $\begin{array}{l}\text { Teacher formal } \\
\text { education }\end{array}$ & $\begin{array}{l}\text { Whether the subject of the target class was included in the teacher's initial formal } \\
\text { education (yes, in ISCED level } 4 \text { or above or in a subject specialisation as part of } \\
\text { teacher training }=1 \text {; otherwise }=0 \text { ) } \\
\text { Whether the pedagogy of the subjects taught was included in the teacher's formal } \\
\text { education (yes, for all or some subjects taught }=1 \text {; no }=0 \text { ) } \\
\text { Whether the classroom practice (practicum, internship or student teaching) of the } \\
\text { subjects taught was included in the teacher's formal education (yes, for all or some } \\
\text { subjects taught }=1 ; \text { no }=0 \text { ) }\end{array}$ \\
\hline $\begin{array}{l}\text { Teacher } \\
\text { professional } \\
\text { development }\end{array}$ & $\begin{array}{l}\text { Index of teacher's participation in effective professional development (ranging from } 5.57 \\
\text { to } 14.31 \text { ). It is composed of teachers' reports of whether their professional development } \\
\text { was characterised by the following elements: } \\
\text { A group of colleagues from my school or subject group } \\
\text { Opportunities for active learning methods (not only listening to a lecturer) } \\
\text { Collaborative learning activities or research with other teachers } \\
\text { An extended time-period (several occasions spread out over several weeks or months) } \\
\text { Participation in professional development covering knowledge and understanding of the } \\
\text { teacher's subject field, with large perceived impact on his/her teaching (yes }=1 \text {; no = } 0 \text { ) } \\
\text { Participation in professional development covering pedagogical competencies in the } \\
\text { teacher's subject field, with large perceived impact on his/her teaching (yes }=1 \text {; no }=0 \text { ) } \\
\text { Participation in professional development covering student behaviour and classroom } \\
\text { management, with large perceived impact on his/her teaching (yes }=1 ; \text { no }=0 \text { ) }\end{array}$ \\
\hline \multicolumn{2}{|c|}{ School Level Variables } \\
\hline Student behaviour & $\begin{array}{l}\text { Percentage of teachers in the school who report having more than } 10 \% \text { of students with } \\
\text { behavioural problems in their target class (from } 0 \text { to } 100 \% \text { ) }\end{array}$ \\
\hline $\begin{array}{l}\text { Student } \\
\text { socioeconomic } \\
\text { background }\end{array}$ & $\begin{array}{l}\text { Percentage of teachers in the school who report having more than } 10 \% \text { of students } \\
\text { from socioeconomically disadvantaged homes in their target class (from } 0 \text { to } 100 \% \text { ) }\end{array}$ \\
\hline School sector & School management (publicly managed school $=1 ;$ privately managed school $=0)^{a}$ \\
\hline $\begin{array}{l}\text { Teacher } \\
\text { engagement in } \\
\text { professional } \\
\text { collaboration }\end{array}$ & $\begin{array}{l}\text { School mean index of professional collaboration (ranging from } 3.93 \text { to } 14.49 \text { ). It is } \\
\text { composed of teachers' reported engagement in the following activities: } \\
\text { Teach jointly as a team in the same class } \\
\text { Observe other teachers' classes and provide feedback } \\
\text { Engage in joint activities across different classes and age groups (e.g. projects) } \\
\text { Take part in collaborative professional learning }\end{array}$ \\
\hline & schools may or may not receive public funding. \\
\hline
\end{tabular}

The second purpose of this paper is to identify the factors that are associated with higher percentages of students with behavioural problems in the class. In other words, it aims to identify the profiles of teachers - and their schools - who report having the highest proportions of students with behavioural problems.

Since the proportion of students with behavioural problems in the classroom is captured by an ordered categorical variable, ordered logistic regressions were conducted to address this research goal. 
The dependent variable was the variable representing the percentage of students with behavioural problems in the target class (where $0 \%=1 ; 1$ to $10 \%=2 ; 11$ to $30 \%=3 ; 31$ to $60 \%=4$; and more than $60 \%=5$ ). In this case, there was a particular interest in investigating not only contextual factors, but also whether higher participation in school decisions (by the school community) was associated with a lower incidence of student misbehaviour. Therefore, the explanatory variables included an index of stakeholder participation in school decisions. All the variables included in this model are described in Table 5.

Table 5. Variables included in the model for the behavioural problems analysis

\begin{tabular}{|c|c|}
\hline \multicolumn{2}{|l|}{ Dependent Variable } \\
\hline Behavioural problems & $\begin{array}{l}\text { Percentage of students with behavioural problems in the target class (where } 0 \%=1 \text {; } \\
1 \text { to } 10 \%=2 ; 11 \text { to } 30 \%=3 ; 31 \text { to } 60 \%=4 ; \text { and more than } 60 \%=5 \text { ). }\end{array}$ \\
\hline \multicolumn{2}{|l|}{ Independent Variables } \\
\hline \multicolumn{2}{|c|}{ Teacher/Class Level Variables } \\
\hline $\begin{array}{l}\text { Student socio- } \\
\text { economic background }\end{array}$ & $\begin{array}{l}\text { Percentage of students from socioeconomically disadvantaged homes in the target } \\
\text { class }(10 \% \text { or less }=0 \text {; more than } 10 \%=1) \text {. }\end{array}$ \\
\hline Teacher experience & Teaching experience (number of years). \\
\hline Class size & Class size (number of students in the target class). \\
\hline \multicolumn{2}{|c|}{ School Level Variables } \\
\hline $\begin{array}{l}\text { Student socio- } \\
\text { economic background }\end{array}$ & $\begin{array}{l}\text { Percentage of teachers in the school who report having more than } 10 \% \text { of students } \\
\text { from socioeconomically disadvantaged homes in their target class (from } 0 \text { to } 100 \% \text { ). }\end{array}$ \\
\hline School size & School size (number of students). \\
\hline School location & $\begin{array}{l}\text { School location, according to population (in cities or large cities, with more than } \\
100,000 \text { inhabitants }=1 ; \text { otherwise }=0 \text { ). }\end{array}$ \\
\hline $\begin{array}{l}\text { Participation among } \\
\text { stakeholders }\end{array}$ & $\begin{array}{l}\text { School mean index of stakeholder participation in school decisions (ranging from } \\
4.53 \text { to } 15.43 \text { ). It is composed of teachers' reports regarding the school climate on } \\
\text { these aspects: } \\
\text { This school provides staff with opportunities to actively participate in school } \\
\text { decisions. } \\
\text { This school provides parents or guardians with opportunities to actively participate in } \\
\text { school decisions. } \\
\text { This school provides students with opportunities to actively participate in school } \\
\text { decisions. } \\
\text { This school has a culture of shared responsibility for school issues. } \\
\text { There is a collaborative school culture which is characterised by mutual support. }\end{array}$ \\
\hline
\end{tabular}

Source: OECD TALIS 2013 database.

All the indices presented in this paper were developed as a part of the TALIS 2013 study and are included in the TALIS 2013 database. These indices were operationally defined by observable items and constructed using complex procedures that involved scaling the items. The complex scales were first evaluated with exploratory factor analysis: confirmatory factor analysis (CFA) was used to construct the scales, and CFA with multiple comparison groups was used to validate the constructed scales. All the details are described in OECD (2014b).

In all the analyses presented in this paper, the regressions were estimated for each country separately.

\section{Results}

The multilevel analysis of the percentage of class time teachers report spending on keeping order in the classroom starts by running an empty model - a model with no independent variables. This allows us to calculate the intraclass correlation coefficient (ICC), which expresses the degree of resemblance between teachers and classes belonging to the same school. The ICC is called a correlation coefficient because it is equal to the correlation between values of two randomly drawn teachers in the same, randomly drawn school (Snijders and Bosker, 1999). The ICC can also be interpreted as the proportion of the total variance of the dependent variable that may be attributed to group level characteristics. The results of the empty model estimation are presented in Table 6. 
EDU/WKP(2015)1

Table 6. Time keeping order analysis - empty model

\begin{tabular}{|c|c|c|c|c|c|c|}
\hline & Brazil & & Chile & & Mexico & \\
\hline Fixed effect & Coefficient & S.E. & Coefficient & S.E. & Coefficient & S.E. \\
\hline Intercept & 19.90 & 0.33 & 15.61 & 0.56 & 12.31 & 0.32 \\
\hline Random part & $\begin{array}{l}\text { Variance } \\
\text { component }\end{array}$ & S.E. & $\begin{array}{l}\text { Variance } \\
\text { component }\end{array}$ & S.E. & $\begin{array}{l}\text { Variance } \\
\text { component }\end{array}$ & S.E. \\
\hline $\begin{array}{l}\text { Level-two } \\
\text { (school) variance }\end{array}$ & 24.35 & 2.95 & 26.47 & 6.21 & 6.94 & 1.99 \\
\hline $\begin{array}{l}\text { Level-one } \\
\text { (teacher) } \\
\text { variance }\end{array}$ & 189.19 & 8.41 & 114.87 & 10.39 & 91.12 & 6.85 \\
\hline $\begin{array}{l}\text { Intraclass } \\
\text { Correlation } \\
\text { Coefficient } \\
\text { (ICC) }\end{array}$ & 0.11 & & 0.19 & & 0.07 & \\
\hline
\end{tabular}

Source: OECD TALIS 2013 database.

As already noted in previous analyses of TALIS 2008 data, most of the variation in teachers' reported use of class time lies between teachers (OECD, 2009). The ICC is 7\% in Mexico, 11\% in Brazil and 19\% in Chile. This means that only $7 \%$ of the variation in the proportion of time teachers report spending keeping order in the classroom in Mexico is due to school level factors, $11 \%$ in Brazil and 19\% in Chile, while the remaining portion of the variation is due to teacher and class level factors.

Even though the between-school variance can be considered small in all three countries, in Chile it is somewhat larger compared to Brazil and Mexico. The high socio-economic status (SES) segregation ${ }^{7}$ of the student population in Chile, which has been receiving increasing attention in the literature, is a plausible explanation for this difference (Elacqua, 2012; Valenzuela et al., 2013). This is not to say that there is no such segregation in Brazil and Mexico. But according to students' responses to the PISA 2009 questionnaire, Chile is one of the countries in which lower proportions of students attend schools with a socio-economically diverse student intake - which mean that the majority of Chilean students attend either advantaged or disadvantaged schools (OECD, 2010). While around 40\% of Brazilian and Mexican students are enrolled in schools with an average or diverse socio-economic intake, only about $20 \%$ of Chilean students are enrolled in such schools.

The next step in the analysis is to add explanatory variables to the equation, in order to test the association between those variables and the time teachers report spending keeping order in the classroom. These variables, in general, are expected to be related to time keeping order in the classroom. Nonetheless, when other factors are considered in the model, their association may not be statistically significant. This would imply that this direct relationship may not exist - it may come from differences in other factors that might be more concentrated in teachers or schools with the characteristics previously tested.

In each table, the coefficients represent the percentage points added or subtracted in terms of proportion of class time spent keeping order for a unit change in the analysed variables, all other variables being held constant. For example, in Table 7, the first line regression coefficients represent the additional percentage points (in terms of proportion of time spent keeping order in a class) for teachers with more than $10 \%$ students with behavioural problems in their class. The second line regression coefficients represent the additional percentage points (again, in terms of proportion of time spent keeping order in a

7. The uneven distribution among schools of children with different social and economic characteristics. 
class) for teachers in schools where all teachers have more than $10 \%$ of their students with behavioural problems in their classes.

Table 7. Time keeping order analysis - estimates with behavioural problems variables

\begin{tabular}{|c|c|c|c|c|c|c|}
\hline & Brazil & & Chile & & Mexico & \\
\hline Fixed effect & Coefficient & S.E. & Coefficient & S.E. & Coefficient & S.E. \\
\hline $\begin{array}{l}\text { More behavioural } \\
\text { problems in class }\end{array}$ & $7.84^{\star * *}$ & 0.56 & $8.00^{* * *}$ & 0.90 & $4.02^{\star * *}$ & 0.49 \\
\hline $\begin{array}{l}\text { More behavioural } \\
\text { problems in school }\end{array}$ & $6.11^{* * *}$ & 1.33 & $7.85^{\star * *}$ & 1.95 & $2.93^{*}$ & 1.50 \\
\hline Intercept & $11.07^{* * *}$ & 0.74 & $7.63^{\star * *}$ & 0.89 & $9.10^{\star * *}$ & 0.74 \\
\hline Random part & $\begin{array}{l}\text { Variance } \\
\text { component }\end{array}$ & S.E. & $\begin{array}{l}\text { Variance } \\
\text { component }\end{array}$ & S.E. & $\begin{array}{l}\text { Variance } \\
\text { component }\end{array}$ & S.E. \\
\hline $\begin{array}{l}\text { Level-two (school) } \\
\text { variance }\end{array}$ & 16.07 & 2.48 & 9.35 & 3.97 & 5.14 & 1.78 \\
\hline $\begin{array}{l}\text { Level-one (teacher) } \\
\text { variance }\end{array}$ & 176.78 & 7.71 & 102.66 & 8.62 & 87.56 & 6.52 \\
\hline $\begin{array}{l}\text { Intraclass } \\
\text { Correlation } \\
\text { Coefficient (ICC) }\end{array}$ & 0.08 & & 0.08 & & 0.06 & \\
\hline
\end{tabular}

As shown in Table 7, teachers who report having more than $10 \%$ of their students with behavioural problems in their class, and teachers who are in schools where all teachers report the same, also report spending much more class time keeping order in Brazil and in Chile than those who don't (the comparison group of teachers). In Mexico, these differences are smaller than in Brazil and Chile.

Results presented in Table 8 show that the association between student SES (reported by teachers) and the time teachers report spending keeping order in the classroom is weaker than the association with student behavioural problems. In fact, in Mexico, there is no significant relationship between these variables. In Brazil, teachers who report having higher proportions of students from lower SES report spending more time keeping order than their colleagues with fewer students from lower SES. In Chile, teachers in schools where all teachers report higher proportions of students from lower SES, also report spending more time keeping order compared to teachers in schools where fewer teachers report high levels of socio-economic disadvantage. 
Table 8. Time keeping order analysis - estimates with socioeconomic variables

\begin{tabular}{|c|c|c|c|c|c|c|}
\hline & Brazil & & Chile & & Mexico & \\
\hline Fixed effect & Coefficient & S.E. & Coefficient & S.E. & Coefficient & S.E. \\
\hline Lower SES in class & $4.02^{\star \star \star}$ & 0.70 & 1.66 & 1.23 & 0.13 & 0.67 \\
\hline $\begin{array}{l}\text { Lower SES in } \\
\text { school }\end{array}$ & 1.21 & 1.29 & $4.94^{* *}$ & 1.96 & -0.93 & 1.25 \\
\hline Intercept & $16.71^{* * *}$ & 0.72 & $11.35^{\star * *}$ & 0.99 & $12.81^{* * *}$ & 0.74 \\
\hline Random part & $\begin{array}{l}\text { Variance } \\
\text { component }\end{array}$ & S.E. & $\begin{array}{l}\text { Variance } \\
\text { component }\end{array}$ & S.E. & $\begin{array}{l}\text { Variance } \\
\text { component }\end{array}$ & S.E. \\
\hline $\begin{array}{l}\text { Level-two (school) } \\
\text { variance }\end{array}$ & 21.63 & 2.79 & 21.85 & 5.38 & 6.91 & 1.98 \\
\hline $\begin{array}{l}\text { Level-one (teacher) } \\
\text { variance }\end{array}$ & 186.79 & 8.25 & 114.94 & 10.33 & 91.26 & 6.87 \\
\hline $\begin{array}{l}\text { Intraclass } \\
\text { Correlation } \\
\text { Coefficient (ICC) }\end{array}$ & 0.10 & & 0.16 & & 0.07 & \\
\hline
\end{tabular}

One might expect that teachers in public schools spend more time keeping order than their peers in private schools, since public schools usually concentrate students from socio-economically disadvantaged homes and the previous regression showed some evidence to support this. But this difference was only observed in Brazil- and it was a small difference of only three percentage points, as Table 9 shows. In Chile, there was no difference in time keeping order among teachers from publicly to privately managed schools, which may seem contradictory to the previously mentioned data on particularly high SES segregation of the student population in the country. This may happen because, in Chile, the category "privately managed schools" includes a very diverse group of schools: from the schools that are $100 \%$ privately funded to the schools that receive most of their funding from the government. So it might be the case that the variable on school type was unable to capture the complexity of school management in Chile.

Table 9. Time keeping order analysis - estimates with type of school management variable (public or private)

\begin{tabular}{|c|c|c|c|c|c|c|}
\hline & Brazil & & Chile & & Mexico & \\
\hline Fixed effect & Coefficient & S.E. & Coefficient & S.E. & Coefficient & S.E. \\
\hline $\begin{array}{l}\text { Publicly managed } \\
\text { school }\end{array}$ & $3.15^{\star * *}$ & 0.77 & 0.84 & 1.31 & -0.66 & 0.75 \\
\hline Intercept & $17.43^{* * *}$ & 0.68 & $15.12^{\star * *}$ & 0.71 & $12.82^{* * *}$ & 0.66 \\
\hline Random part & $\begin{array}{l}\text { Variance } \\
\text { component }\end{array}$ & S.E. & $\begin{array}{l}\text { Variance } \\
\text { component }\end{array}$ & S.E. & $\begin{array}{l}\text { Variance } \\
\text { component }\end{array}$ & S.E. \\
\hline $\begin{array}{l}\text { Level-two (school) } \\
\text { variance }\end{array}$ & 21.67 & 2.84 & 30.41 & 7.23 & 6.91 & 2.02 \\
\hline $\begin{array}{l}\text { Level-one (teacher) } \\
\text { variance }\end{array}$ & 189.26 & 8.47 & 112.43 & 10.35 & 91.50 & 6.88 \\
\hline $\begin{array}{l}\text { Intraclass } \\
\text { Correlation } \\
\text { Coefficient (ICC) }\end{array}$ & 0.10 & & 0.21 & & 0.07 & \\
\hline
\end{tabular}

Note: ${ }^{* * *}$ denotes $1 \%$ significance level; ${ }^{* *}$ denotes $5 \%$ significance level; ${ }^{*}$ denotes $10 \%$ significance level.

Source: OECD TALIS 2013 database. 
Nonetheless, there are some relevant changes in the results once all the explanatory variables are included in the model. These results are presented in Table 10.

Table 10. Time keeping order analysis - full model

\begin{tabular}{|c|c|c|c|c|c|c|}
\hline & Brazil & & Chile & & Mexico & \\
\hline Fixed effect & Coefficient & S.E. & Coefficient & S.E. & Coefficient & S.E. \\
\hline $\begin{array}{l}\text { More behavioural problems } \\
\text { in class }\end{array}$ & $7.33^{\star \star \star}$ & 0.68 & $7.73^{\star * *}$ & 1.04 & $3.66^{* * *}$ & 0.48 \\
\hline $\begin{array}{l}\text { More behavioural problems } \\
\text { in school }\end{array}$ & $5.61^{* * *}$ & 2.07 & $5.74^{* *}$ & 2.42 & 3.67 & 2.34 \\
\hline Lower SES in class & 1.41 & 0.93 & 0.61 & 1.65 & -1.13 & 0.73 \\
\hline Lower SES in school & -1.23 & 2.12 & 0.57 & 2.48 & -2.07 & 2.55 \\
\hline Publicly managed school & 1.69 & 1.21 & -1.01 & 1.42 & -0.09 & 1.82 \\
\hline $\begin{array}{l}\text { Years of teaching } \\
\text { experience }\end{array}$ & $-0.10^{* *}$ & 0.04 & $-0.10^{* *}$ & 0.04 & $-0.06^{* *}$ & 0.03 \\
\hline Teacher gender (female) & $1.27^{\star \star}$ & 0.60 & -0.28 & 1.01 & $1.49^{\star \star *}$ & 0.46 \\
\hline $\begin{array}{l}\text { Class size } \\
\text { The subject of the class }\end{array}$ & -0.02 & 0.03 & -0.03 & 0.05 & 0.09 & 0.04 \\
\hline $\begin{array}{l}\text { was included in the initial } \\
\text { training }\end{array}$ & -0.16 & 0.89 & $-5.87^{* * *}$ & 1.97 & -1.41 & 0.98 \\
\hline $\begin{array}{l}\text { The pedagogy of subjects } \\
\text { taught was included in } \\
\text { formal education }\end{array}$ & $-1.69^{*}$ & 0.94 & -1.39 & 2.14 & $-2.15^{\star}$ & 1.24 \\
\hline $\begin{array}{l}\text { The practice of subjects } \\
\text { taught was included in } \\
\text { formal education }\end{array}$ & 0.56 & 1.10 & 0.19 & 1.51 & -0.02 & 0.81 \\
\hline $\begin{array}{l}\text { Had PD on the knowledge } \\
\text { of the subject with large } \\
\text { impact }\end{array}$ & 0.30 & 0.66 & 1.55 & 1.50 & -0.10 & 0.65 \\
\hline $\begin{array}{l}\text { Had PD on student } \\
\text { behaviour and classroom } \\
\text { management with large } \\
\text { impact }\end{array}$ & -1.11 & 0.86 & -0.31 & 1.42 & -0.59 & 0.63 \\
\hline $\begin{array}{l}\text { Had PD on pedagogical } \\
\text { competencies of the subject } \\
\text { with large impact }\end{array}$ & -1.19 & 0.73 & -1.81 & 1.46 & $-1.90^{\star * *}$ & 0.71 \\
\hline $\begin{array}{l}\text { Professional collaboration } \\
\text { in school index }\end{array}$ & $-0.82^{\star \star}$ & 0.32 & $-1.29^{* * *}$ & 0.42 & 0.00 & 0.36 \\
\hline $\begin{array}{l}\text { Participation on effective } \\
\text { PD index }\end{array}$ & $-0.41^{* * *}$ & 0.15 & 0.14 & 0.24 & -0.08 & 0.13 \\
\hline Intercept & $22.32^{\star \star \star}$ & 3.70 & $27.67^{\star \star \star}$ & 4.39 & $12.61^{\star \star \star}$ & 4.81 \\
\hline Random part & $\begin{array}{l}\text { Variance } \\
\text { component }\end{array}$ & S.E. & $\begin{array}{l}\text { Variance } \\
\text { component }\end{array}$ & S.E. & $\begin{array}{l}\text { Variance } \\
\text { component }\end{array}$ & S.E. \\
\hline \multirow{2}{*}{$\begin{array}{l}\text { Level-two (school) variance } \\
\text { Level-one (teacher) } \\
\text { variance }\end{array}$} & 13.93 & 2.77 & 13.90 & 14.82 & 8.10 & 4.06 \\
\hline & 165.39 & 9.80 & 87.16 & 10.67 & 72.47 & 5.81 \\
\hline $\begin{array}{l}\text { Intraclass Correlation } \\
\text { Coefficient (ICC) }\end{array}$ & 0.08 & & 0.14 & & 0.10 & \\
\hline
\end{tabular}

Note: ${ }^{* \star \star}$ denotes $1 \%$ significance level; ${ }^{* \star}$ denotes $5 \%$ significance level; ${ }^{*}$ denotes $10 \%$ significance level.

Source: OECD TALIS 2013 database. 
As Table 10 shows, behavioural problems are still highly associated with the time teachers report spending keeping order. This is particularly true in Brazil and Chile, where teachers who report having more than $10 \%$ of students with behavioural problems in their class, report spending around 7 percentage points more of their time keeping order than their colleagues with fewer students with behavioural problems in their class. The same is true for teachers in schools where all teachers report higher percentages of students with behavioural problems in their class: these teachers report spending around 6 percentage points more of their time keeping order compared to their colleagues. Considering that the average proportion of time spent keeping order by Brazilian and Chilean teachers is, respectively, 20\% and $15 \%$ of class time, these are important differences.

At the same time, in the full model, socio-economic background and working in a publicly managed school do not seem to be associated with the reported time keeping order in any of the countries. Rather, it appears that the differences between teachers from public and private schools or, according to SES presented in Tables 8 and 9, come from differences in other factors that might be more concentrated in one of these types of schools - and not by the type of school management itself.

Teacher experience shows one of the most consistent associations with the reported time keeping order in the classroom, though still of small magnitude. In all three countries, the more experienced a teacher is, the less time he or she reports spending keeping order. In Brazil and Chile, for each additional year of experience, the average time spent keeping order is reduced by 0.1 percentage point. In Mexico, it is reduced by 0.6 percentage point. This means that, for example, in Brazil and Chile, a teacher with 30 years of experience spends 3 percentage points less time keeping order than a new teacher, while in Mexico this difference is 1.8 percentage point.

Female teachers spend more time keeping order in the classroom than male teachers in Brazil and Mexico. There is a difference of 1.3 percentage points in Brazil and 1.5 percentage points in Mexico.

Interestingly, there is no significant association between class size and the time spent keeping order in the classroom, which means there is no evidence of a direct relationship between these two factors in this analysis.

There are also some interesting results linking teacher education and time keeping order in the classroom. In Chile, teachers who had the subject of the class taught included in their formal education, report spending less time keeping order in the classroom. And the difference is relatively large: 5.9 percentage points, similar to the effect reported for behavioural problems in the school. In Brazil and Mexico, teachers who had the pedagogy of the subjects taught included in their formal education, report spending less time keeping order in the classroom - 1.7 percentage points and 2.2 percentage points less, respectively.

There is also some evidence linking teacher professional development (PD) and time keeping order in the classroom. In Mexico, teachers who participated in PD with a focus on pedagogical competences of the subject they teach, and who perceived a large impact on their teaching, report spending 1.9 percentage points less of their class time keeping order in the classroom. In Brazil, the higher the score of a teacher on the effective PD participation index, the lower the reported time spent keeping order in the classroom. For each unit change in the score, teachers report spending 0.4 percentage point less keeping order. Since the scores range from 5.6 to 14.3 (around 9 units), the difference between teachers with the lowest and the highest scores in the effective PD participation index may reach 3.7 percentage points of class time.

In Brazil and Chile, teachers who report higher levels of professional collaboration in their schools report spending less time keeping order in the classroom. For each unit change in the score, Brazilian teachers report spending 0.8 percentage point less and Chilean teachers report spending 1.3 percentage 
points less in keeping order. Since the scores range from 3.9 to 14.5 (around 10 units), the difference between teachers with the lowest and the highest scores in the index of professional collaboration may reach 8 percentage points in Brazil and almost 13 percentage points in Chile. These are large differences similar to the one related to behavioural problems in the school in Brazil and larger than this in Chile.

Since such a strong association between the levels of behavioural problems and the time teachers spend keeping order in the classroom was found, this paper also investigates which factors are associated with reported behavioural problems in the classroom. As mentioned previously, ordered logistic regressions are used to address this research goal, since the dependent variable is a categorical one: the percentage of students with behavioural problems in the target class (where $0 \%=1 ; 1$ to $10 \%=2 ; 11$ to $30 \%=3 ; 31$ to $60 \%=4$; and more than $60 \%=5$ ).

The results of the next regressions are presented in terms of odds ratios, to make data more interpretable in terms of probability. Odds ratios should be interpreted in such a way that for a unit change in the predictor variable (e.g., working in a publicly managed school), the odds ratio of the outcome variable (e.g., category $2=$ between 1 and $10 \%$ of students with behavioural problems), relative to the previous category (e.g., category $1=0 \%$ students with behavioural problems), is expected to change by a factor of the respective parameter estimate, all other variables in the model being held constant. Odds ratios higher than 1 indicate an increase in probability while odds ratios below 1 indicate a decrease in probability.

Table 11. Behavioural problems analysis

\begin{tabular}{|c|c|c|c|c|c|c|}
\hline & Brazil & & Chile & & Mexico & \\
\hline & Odds Ratio & S.E. & Odds Ratio & S.E. & Odds Ratio & S.E. \\
\hline Publicly managed school & 0.91 & 0.14 & 1.25 & 0.29 & 0.64 & 0.21 \\
\hline Lower SES in class & $4.88^{* \star *}$ & 0.40 & $2.54^{\star \star \star}$ & 0.49 & $3.53^{\star \star *}$ & 0.38 \\
\hline Lower SES in school & 0.97 & 0.23 & 1.65 & 0.55 & 1.07 & 0.41 \\
\hline Years of teaching experience & $0.98^{\star \star *}$ & 0.00 & $0.96^{\star * *}$ & 0.01 & $0.98^{\star * *}$ & 0.00 \\
\hline Class size & $1.01^{* \star *}$ & 0.00 & 1.00 & 0.01 & 1.00 & 0.00 \\
\hline School size & 1.00 & 0.00 & 1.00 & 0.00 & 1.00 & 0.00 \\
\hline $\begin{array}{l}\text { School located in a city or a } \\
\text { large city }\end{array}$ & $1.32^{* * *}$ & 0.13 & $1.48^{*}$ & 0.34 & 1.23 & 0.15 \\
\hline $\begin{array}{l}\text { Participation among } \\
\text { stakeholders index }\end{array}$ & $0.93^{*}$ & 0.04 & $0.81^{\star * *}$ & 0.05 & $0.88^{\star * \star}$ & 0.03 \\
\hline
\end{tabular}

Source: OECD TALIS 2013 database.

As Table 11 shows, teachers who report having more than $10 \%$ of students from socio-economically disadvantaged homes in their target class are approximately 1.5 times more likely to report being in a higher category in terms of proportions of students with behavioural problems in the classroom in Chile, 2.5 times more in Mexico and almost 4 times more in Brazil. Since there are five categories of the dependent variable, this means that, on average, a teacher who reports having more than $10 \%$ of students from low SES in the class is 6 times more likely (i.e. 1.5 times higher probability for each higher category) to have more than $60 \%$ students with behavioural problems than to have none in Chile, 10 times in Mexico and 16 times in Brazil. But this relationship was not found at the school level. These results may either indicate that this relationship is present only at the classroom level or that teachers' individual perceptions of student behaviour are biased by their perception on student socio-economic background - or vice-versa. 
As was observed in the time keeping order analysis, working in a publicly managed school does not seem to be associated with the proportion of students with behavioural problems in the classroom, in any of the countries.

In all three countries, the more experienced a teacher, the less likely he or she is to report being in a higher category in terms of proportions of students with behavioural problems in the classroom. In Brazil and Mexico, for each additional year of experience, a teacher is $2 \%$ less likely to report being in a higher category in terms of proportions of students with behavioural problems in the classroom. In Chile, this decrease is $4 \%$ for each year of experience. This means that, for example, in Chile a teacher with 20 years of experience is 3.2 times less likely to report having more than $60 \%$ of students with behavioural problems in their classroom than to report having none, in comparison with a teacher that has just been hired.

In Brazil, the larger the class size, the higher the odds that the teacher will report having higher percentages of student with behavioural problems in the classroom: 1\% more for each additional student in the class. This means that, for example, a teacher with 40 students in the class is $80 \%$ more likely to report having more than $60 \%$ of students with behavioural problems than to report having none, compared to a teacher with 20 students in the class. This association was not found in Chile or Mexico.

In Brazil and Chile, teachers in schools located in cities or large cities (with more than 100000 inhabitants) are $32 \%$ and $48 \%$, respectively, more likely to report being in a higher category in terms of proportions of students with behavioural problems in the classroom. This means that, on average, a teacher in a school located in cities with more than 100000 inhabitants is 1.3 times more likely to have more than $60 \%$ students with behavioural problems, than to have none compared to a teacher in a school located in cities with less people in Brazil this figure increases to almost 2 times in Chile.

Importantly, in all three countries, teachers who report higher levels of participation among stakeholders in their schools are less likely to be in a higher category, in terms of proportions of students with behavioural problems in the classroom. For each unit change in the score, Brazilian teachers are 7\% less likely to report being in a higher category, in terms of proportions of students with behavioural problems in the classroom, while Mexican teachers are $12 \%$ less likely and Chilean teachers are $19 \%$ less likely to report the same. Since the scores range from 4.5 to 15.4 (around 11 units), this means that a teacher who reports the lowest score on the participation among stakeholders index is 2.8 times more likely to have more than $60 \%$ students with behavioural problems than to have none, compared to a teacher who reports the highest score in the participation among stakeholders index in Brazil, 5.2 times more in Mexico and 8.3 times more in Chile.

\section{Conclusions}

Figure 3 presents a framework combining the evidence obtained from both sets of analyses in this paper. The boxes in black indicate the factors that were significantly associated with the variables of interest in the three countries. The boxes in medium grey indicate the factors that were significantly associated with the variables of interest in two countries. And the boxes in light grey indicate the factors that were significantly associated with the variables of interest in one country. 
Figure 3. Framework of results

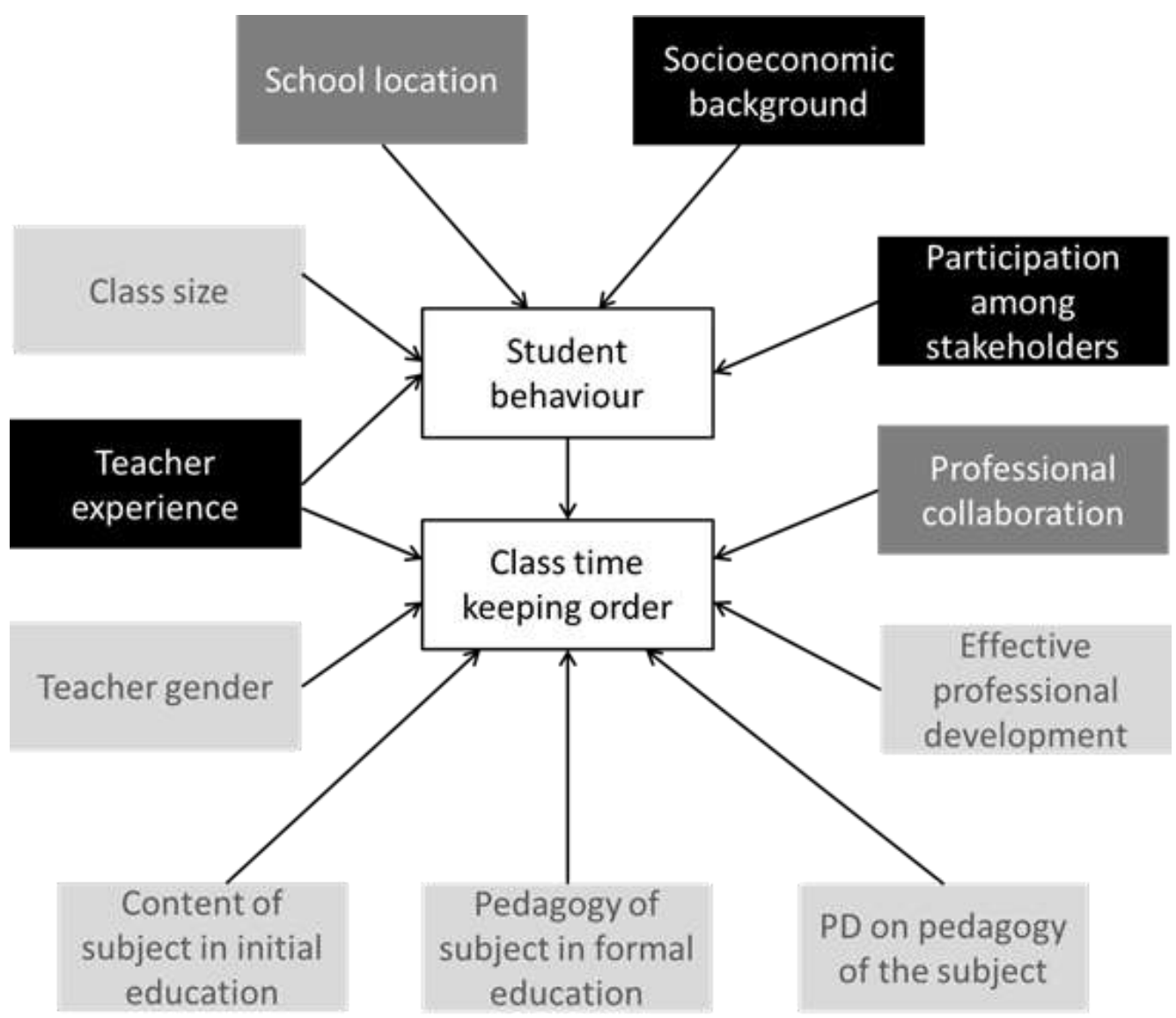

Source: Produced by the authors.

As previously noted, teachers' perception of the time they spend keeping order in the classroom is highly associated with their perception of the proportion of students with behavioural problems in their classes. This is the case not only at the individual level, but also when the perception of the group of teachers from the same school is taken into account - with the exception of Mexico. Therefore, to improve the use of class time it is important to understand what is associated with student behaviour and the time spent by teachers keeping order in the classroom.

In all three countries analysed, it was shown that teachers who work in schools with higher reported levels of participation among stakeholders are less likely to report high proportions of students with behavioural problems in their class. These results show that participation in school decisions, combined with a culture of shared responsibility and mutual support, can be associated with lower incidences of student misbehaviour. Therefore, a good starting point to improve school climate may be to create or improve mechanisms to promote students', parents' and staff participation in school decisions with shared responsibility, including decisions on school behaviour policies (Porter, 2006).

Teachers from schools located in larger cities report having more students with behavioural problems in their classes - with the exception of Mexico. Larger cities may present more challenges in terms of inequalities, violence and other social problems that have an effect on school climate. This evidence suggests that schools in larger cities should receive differentiated attention when policies to improve school climate are developed at the system level. 
Only in Brazil is class size is associated to student behavioural problems. In the three countries studied, the average class size is near 30 students, which can be considered high in comparison with the TALIS 2013 average of 24 students per class. However, the major concern should not be the average, but the fact that some classes are much larger, with around 50 students. Initiatives to reduce the size of these particularly large classes should be a priority, in Brazil at least in an attempt to improve the conditions for teachers to engage students in learning.

The number of years' experience a teacher has plays an important role in all three countries. Less experienced teachers are more likely to report having more students with behavioural problems and to spend more time keeping order in the classroom. Possible explanations for these results include: (1) throughout their careers, teachers improve their ability to provide effective teaching and classroom management; (2) more experienced teachers have priority when it comes to selecting schools and classes, and therefore tend to choose the ones where students have good behaviour; (3) some combination of these hypotheses. In any case, allocating more experienced teachers to classes with more challenging disciplinary climate as well as encouraging them to mentor less experienced teachers, could help reduce time spent keeping order in the classroom.

In Brazil and Mexico, female teachers were shown to spend more time keeping order in the classroom than male teachers. This evidence raises questions, to be further investigated, about gender-related differences in teaching and classroom management styles, and also in student-teacher relations.

Having the content of the subject taught - in Chile - and the pedagogy of the subjects taught - in Brazil and Mexico - included in teachers' formal education is negatively associated with the reported time keeping order in the classroom. In both cases, the hypothesis is that teachers who have content knowledge and pedagogical content knowledge are better prepared to teach in ways that engage students in learning, thereby reducing the need to keep order in the classroom.

Due to the lack of attractiveness of teaching, it is still common to find teachers who have not completed a teacher initial education programme, or who have not received training in the subjects taught in Latin America. This complex problem requires solutions that involve not only improving initial teacher education but also teaching careers and working conditions, in order to attract and maintain qualified people to the teaching profession.

There is some evidence of an association between teacher professional development and time keeping order in the classroom. Teachers who participated in PD focused on the pedagogy of the subjects taught in Mexico, those who report higher levels of participation in effective forms of PD in Brazil, and those who report higher levels of professional collaboration in their schools in Brazil and Chile report spending less time keeping order in their classrooms. All these initiatives focused on supporting teachers to improve their teaching skills and to engage students in learning may help to improve the classroom climate.

It should also be highlighted that student behaviour and time spent keeping order are not associated with the type of school management. Therefore, evidence provided by this paper should support policies to improve student engagement and classroom climate in schools from both the public and private sectors in Latin America.

Following these data analyses, two case studies (in Ontario, Canada and in England) were conducted in order to better understand the types of policies that may be implemented, to support teachers and schools in improving disciplinary climate. The main purpose of these case studies is, along with the TALIS 2013 data analysis, to provide policy recommendations to educational systems in which disciplinary climate is a major concern, such as Brazil, Chile, and Mexico as well as many other countries. These case studies will be published as a separate OECD Working Paper at a later date. 


\section{REFERENCES}

Abadzi, H. (2007). Instructional time loss and local level governance. Prospects, vol. XXXVII, no. 1, March 2007.

Benavot, A. and Gad, L. (2004). Actual instructional time in African primary schools: factors that reduce school quality in developing countries. Prospects, vol. XXXIV, no. 3, 291-310.

Carnoy, M., Gove, A. K. and Marshall, J. H. (2009) A vantagem acadêmica de Cuba: por que seus alunos vão melhor na escola. São Paulo: Ediouro.

Cotton, K. (1989). Educational time factors. Close up \#8. Portland, OR: Northwest Regional Educational Laboratory.

Darling-Hammond, L. and Lieberman, A. (2012). Teacher Education around the world: what can we learn from international practices? In: Darling-Hammond, L.; Lieberman, A. (eds.), Teacher Education around the World. Routledge: London.

Darling-Hammond, L. and McLaughlin, M. (1995). Policies that support professional development in an era of reform. Phi Delta Kappan, 76, 8, 597-604.

Darling-Hammond, L., Wei, R., Andree, A., Richardson, N. and Orphanos, S. (2009). Professional learning in the learning profession: A status report on teacher development in the United States and abroad. National Staff Development Council.

Darling-Hammond, L., Wise, A. E., and Klein, S. P. (1999). A License To Teach: Raising Standards for Teaching. San Francisco, CA: Jossey-Bass.

Davis, C., Nunes, M. and Almeida, P. (2011). Formação continuada de professores: uma análise das modalidades e das práticas em estados e municípios brasileiros. Estudos \& Pesquisas Educacionais, n.2, p. 81-166.

De La Cruz, M., Scheuer, N., Caíno, G., Huarte, M., Baudino, V. and Ayastuy, R. (2001). El discurso en clase de maestros de nivel primario en distintos sectores socioculturales. Estudios pedagógicos, n. 27, pp. 33-41.

Desimone, L., Porter, A., Garet, M., Yoon, K. and Birman, B. (2002). Effects of professional development on teachers' instruction: results from a three-year longitudinal study. Educational Evaluation and Policy Analysis, Vol. 24, No. 2, pp. 81-112.

Desimone, L. (2009). Improving impact studies of teachers' professional development: toward better conceptualizations and measures. Educational Researcher, 38, 3, 181-199.

Educational Assessment and Research Centre (EARC) (2003). Teacher time-on-task. Washington, DC: World Bank.

Elacqua, G. (2012). The impact of school choice and public policy on segregation: Evidence from Chile. International Journal of Educational Development, 32, 444-453. 
Espin, C., Yell, M. (2001). Critical indicators of effective teaching for preservice teachers: relationships between teaching behaviours and ratings of effectiveness. Teacher Education and Special Education, 17, 154-169.

Garet, M., Birman, B., Porter, A., Desimone, L. and Herman, R. (1999). Designing effective professional development: Lessons from the Eisenhower Program [and] technical appendices. American Institutes for Research.

Garet, M., Porter, A., Desimone, L., Birman, B. and Yoon, K. (2001). What makes professional development effective? Results from a national sample of teachers. American Educational Research Journal, vol. 38, n. 4, 915-945.

Gettinger, M. and Seibert, J. (2002). Best practices in increasing academic learning time. Best practices in school psychology, IV, v. 1, p. 773-787.

González, J., Preiss, D. and San Martín, E. (2008). Evaluando el discurso docente: Desarrollo de un modelo de Rasch a partir de la evidencia audiovisual de profesores chilenos de primer ciclo de educación básica en el área de lenguaje. Revista Iberoamericana de Evaluación Educativa, v. 1, n. 2, pp. 137-147.

Goodwin, A. (2012). Quality teachers, Singapore style. In: Darling-Hammond, L.; Lieberman, A. (eds.), Teacher Education around the World. Routledge: London.

Hawley, D., Rosenholtz, S., Goodstein, H. and Hasselbring, T. (1984). Good Schools: What Research Says about Improving Student Achievement. Peabody Journal of Education, Vol. 61, No. 4, pp. iii-vi+1178.

Hawley, D. and Valli, L. (1999). The essentials of effective professional development: a new consensus. In: Darling-Hammond, L.; Sykes, G. (eds.) Teaching as the learning profession: handbook of policy and practice. San Francisco: Jossey-Bass.

Hollowood, T., Salisbury, C., Rainforth, B. and Palombaro, M. (1995). Use of instructional time in classrooms serving students with and without severe disabilities. Exceptional Children, Vol. 61(3), 242-252.

Husu, J. (2003). What a difference a discipline approach makes? Constructing performing quality in teacher-student relations. Paper presented at the Biennial Conference of the European Association for Research on Learning and Instruction in Padua, Italy.

Jensen, B., Sandoval-Hernández, A., Knoll, S. and Gonzalez, E. (2012). The Experience of New Teachers: Results from TALIS 2008. Paris: OECD Publishing.

Karweit, N. (1984). Time-on-task reconsidered: synthesis of research on time and learning. Educational Leadership, May 1984, 32-35.

Karweit, N. and Slavin, R. (1981). Measurement and modeling choices in studies of time and learning. American Educational Research Journal, vol. 18, n. 2, 157-171.

Lieberman, A. (1995). Practices that Support Teacher Development: Transforming Conceptions of Professional Learning. Innovating and Evaluating Science Education: NSF Evaluation Forums, 1992-94, p. 67-78. 
Martinic, S. and Vergara, C. (2007). Gestión del tiempo e interacción del profesor-alumno en la sala de clases de establecimientos con jornada escolar completa en Chile. Revista Electrónica Iberoamericana sobre Calidad, Eficacia y Cambio en Educación, vol. 5, No. 5e., pp. 3-20.

Martinic, S., Vergara, C. and Huepe, D. (2013). Uso del tiempo e interacciones en la sala de clases. Un estudio de caso en Chile. Pro-Posições, v. 24, n. 1 (70), 123-135.

McCormack, A. (1997). Classroom management problems, strategies, and influences in physical education. European Physical Review, 3(2), 102-115.

OECD (2014a) TALIS 2013 Results: An International Perspective on Teaching and Learning. Paris: OECD Publishing.

OECD (2014b) TALIS 2013 Technical Report. Paris: OECD Publishing.

OECD (2010) PISA 2009 Results: Overcoming Social Background - Equity in Learning Opportunities and Outcomes (Volume II). Paris: OECD Publishing.

OECD (2009) Creating effective teaching and learning environments: first results from TALIS. Paris: OECD Publishing.

Oliver, R., Wehby, J. and Reschly, D. (2011). Teacher classroom management practices: effects on disruptive or aggressive student behaviour. Campbell Systematic Reviews 2011.4.

Porter, L. (2006). Behaviour in schools: theory and practice for teachers. Maidenhead: Open University Press.

Preiss, D. (2009). The Chilean instructional pattern for the teaching of language: A video-survey study based on a national program of assessment of teaching. Learning and Individual Differences, 19, 1-11.

Ratcliff, N., Jones, C., Costner, R., Savage-Davis, E., Sheehan, H. and Hunt, G. (2010). Teacher Classroom Management Behaviours and Student Time-on-Task: Implications for Teacher Education. Action in Teacher Education, 32:4, p. 38-51.

Raudenbush, S. and Bryk, A. (2002). Hierarchical linear models: applications and data analysis methods. Thousand Oaks, CA: SAGE Publications.

Sahlbergh, P. (2012). The most wanted: Teachers and teacher education in Finland. In: Darling-Hammond, L.; Lieberman, A. (eds.), Teacher Education around the World. Routledge: London.

Scheerens, J., Hendricks, M. (2014). State of Art of Time Effectiveness. In: Scheerens, J. (ed.) Effectiveness of Time Investments in Education: Insights from a Review and Meta-Analysis. Springer International Publishing.

Shulman, L. (1987). Knowledge and Teaching. Foundations of the New Reform. Harvard Educational Review, Vol. 57, No1. 
Smith, B. (1998). It's about time: Opportunities to learn in Chicago's Elementary Schools. Consortium on Chicago School Research.

Snijders, T. and Bosker, R. (1999). Multilevel Analysis: An Introduction to Basic and Advanced Multilevel Modeling. Thousand Oaks, CA: SAGE Publications.

Supovitz, J., Mayer, D. and Kahle, J. (2000). Promoting inquiry-based instructional practice: the longitudinal impact of professional development in the context of systemic reform. Educational Policy, vol. 14, n. 3, 331-356.

Supovitz, J, Turner, H. (2000). The effects of professional development on science teaching practices and classroom culture. Journal of Research in Science Teaching, v. 37, n. 9, 963 980.

Tartuce, G., Nunes, M. and Almeida, P. (2010). Alunos do ensino médio e a atratividade da carreira docente no Brasil. Cadernos de Pesquisa, v. 40, n. 140, p. 445-477.

Valenzuela, J., Bellei, C. and Ríos, D. (2014). Socioeconomic segregation in a market-oriented school system: The case of Chile. Journal of Education Policy, 29(2), 217-241. 